\title{
RELEVANT ISSUES OF INTENSIFICATION OF DOMESTIC LIVESTOCK PRODUCTION
}

\section{ОТАНДЫҚ МАЛ ШАРУАШЫЛЫҒЫН ҚАРҚЫНДАТУДЫН ӨЗЕКТІ МӘСЕЛЕЛЕРІ}

\section{АКТУАЛЬНЫЕ ПРОБЛЕМЫ ИНТЕНСИФИКАЦИИ ОТЕЧЕСТВЕННОГО ЖИВОТНОВОДСТВА}

\author{
A.A. NURGALIYEVA ${ }^{1 *}$ \\ C.E.SC., Associate Professor \\ K.E. KHASSENOVA ${ }^{2}$ \\ C.E.Sc., Associate Professor \\ G. KENZHETAYEVA ${ }^{1}$ \\ Master of Economics \\ 1 Toraigyrov University, Pavlodar, Kazakhstan \\ 2Shakarim University, Semey, Kazakhstan \\ *corresponding author e-mail: nurgalieva_ainash@mail.ru \\ A.A. НУРГАЛИЕВА ${ }^{1 *}$ \\ э.ғ.к., қаумдастырылған профрессор \\ K.E. XACEHOBA \\ э.ғ.к., қаумдастырылған профрессор \\ Г.К. КЕНЖЕТАEBA ${ }^{1}$ \\ экономика магистрі \\ ${ }^{1}$ Торайғыров университеті, Павлодар, Қазақстан \\ 2 Шәкәрім атындағы университеті, Семей, Қазақстан \\ *автордың электрондық поштасы: nurgalieva_ainash@mail.ru \\ A.A. НУРГАЛИЕВА ${ }^{1 *}$ \\ К.Э.н., ассоциированный профрессор \\ K.E. ХACEHOBA ${ }^{2}$ \\ К.Э.Н., ассоцированный профрессор \\ Г.К. КЕНЖЕТАEВА \\ магИстр эКономики \\ 1 Торайгыров университет, Павлодар, Казахстан \\ ${ }^{2}$ Университет им. Шакарима, Семей, Казахстан \\ *электронная почта автора: nurgalieva_ainash@mail.ru
}

\begin{abstract}
Aim - the article is devoted to the analysis of the current state of the livestock production of the Republic of Kazakhstan in the context of the regions. Methods - analysis, synthesis, systems approach, logical. Results - the dynamics of the population number of livestock and poultry in the republic by farm categories for the period 2018-2020, indicators of gross livestock production are presented. It is noted that agricultural sector, being one of the priority directions of the country's economic development, has great potential and significant reserves, almost all types of agricultural crops of the temperate climatic zone are grown, and the volume of livestock products is increasing. The article discusses the production of ready-made feed for farm animals in kind by regions. The authors state that currently one of the relevant issues in the development of the agro-industrial complex is the low level of labor productivity due to low automation and digitalization of technological processes. The need to meet the demand for livestock products on domestic market of Kazakhstan, as well as to increase its export resources, sets the priority tasks for Kazakhstani science and practice aimed to develop, scientifically justify and master modern technologies for production of low-cost, environmentally friendly, and competitive goods. They should be resource-saving, aimed at maximizing the use and improvement of the genetic potential of farm animals, adapted to the specific natural and economic conditions of the republic. Conclusions - the development and mastering of such innovations will reduce the negative impact on the environment, enable the effective use of material, land and water resources. The main problems hindering the effective development of the livestock industry in the Republic of Kazakhstan are identified, its promising directions are determined.
\end{abstract}


Аңдатпа. Мақсаты - мақала аймақтар бойынша Қазақстан Республикасының мал шаруашылығы саласының қазіргі жай-күйін талдауға арналған. Әдістері - талдау, синтез, жүйелік тәсіл, логикалық. Нәтижелері - 2018-2020жж. аралығындағы шаруашылық санаттары бойынша республикадағы мал мен құс санының динамикасы, мал шаруашылығының жалпы өнімінің көрсеткіштері ұсынылған. Аграрлық сектор ел экономикасын дамытудың басым бағыттарының бірі бола отырып, үлкен әлеуетке және елеулі резервтерге ие, қоңыржай климаттық белдеуде ауыл шаруашылығы дақылдарының барлық түрлері өсіріледі, мал шаруашылығы өнімдерінің көлемі ұлғаюда. Мақалада облыстар бойынша ауыл шаруашылығы малдарына арналған заттай түрдегі дайын жемшөп өндірісі қарастырылады. Авторлар қазіргі уақытта агроөнеркәсіптік кешенді дамытудың өзекті мәселелерінің бірі - технологиялық процестерді автоматтандыру мен цифрландырудың төмендігі салдарынан еңбек өнімділігінің төмен деңгейі екенін атап өткен. Қазақстанның ішкі нарығында мал шаруашылығы өніміне сұранысты қанағаттандыру, сондай-ақ оның экспорттық ресурстарын ұлғайту қажеттілігі қазақстандық ғылым мен практиканың алдына шығыны аз, экологиялық таза, бәсекеге қабілетті тауарлар өндірудің қазіргі заманғы технологияларын әзірлеудің, ғылыми негіздеудің және игерудің бірінші кезектегі міндеттерін қояды. Олар республиканың нақты табиғи және экономикалық жағдайларына бейімделген ауыл шаруашылығы малдарының генетикалық әлеуетін барынша пайдалануға және жақсартуға бағытталған ресурс үнемдеуші болуға тиіс. Қортындылар - мұндай жаңалықтарды дамыту және игеру қоршаған ортаға теріс әсерді әлсіретуге, материалдық, жер және су ресурстарын тиімді пайдалануға мүмкіндік береді. Қазақстан Республикасының мал шаруашылығы саласының тиімді дамуын тежейтін негізгі проблемалар анықталған, оның перспективалық бағыттары айқындалған.

Аннотация. Цель - статья посвящена анализу современного состояния животноводческой отрасли Республики Казахстан в разрезе регионов. Методы - анализа, синтеза, системного подхода, логический. Результаты - представлены динамика численности скота и птицы в республике по категориям хозяйств за период 2018-2020гг., показатели валовой продукции животноводства. Отмечается, что аграрный сектор, являясь одним из приоритетных направлений развития экономики страны, обладает большим потенциалом и значительными резервами, выращиваются практически все виды сельскохозяйственных культур умеренного климатического пояса, наращиваются объемы животноводческих продуктов. В статье рассматривается производство готовых кормов для сельскохозяйственных животных в натуральном выражении по областям. Авторы констатируют, что в настоящее время одна из актуальных проблем развития агропромышленного комплекса - невысокий уровень производительности труда вследствие низкой автоматизации и цифровизации технологических процессов. Необходимость удовлетворения спроса на животноводческую продукцию на внутреннем рынке Казахстана, а также увеличения ее экспортных ресурсов ставит перед казахстанской наукой и практикой первоочередные задачи разработки, научного обоснования и освоения современных технологий производства низкозатратных, экологически чистых, конкурентоспособных товаров. Они должны быть ресурсосберегающими, направленными на максимальное использование и улучшение генетического потенциала сельскохозяйственных животных, адаптированными к конкретным природным и экономическим условиям республики. Выводы - развитие и освоение таких нововведений позволит ослабить негативное влияние на окружающую среду, эффективно использовать материальные, земельные и водные ресурсы. Выявлены основные проблемы, сдерживающие эффективное развитие отрасли животноводства Республики Казахстан, определены ее перспективные направления.

Key words: agro-industrial complex, livestock production industry, agricultural entities, population number of livestock and poultry, material, land, water resources, low-cost, environmentally friendly, competitive products.

Түйінді сөздер: агроөнеркәсіптік кешен, мал шаруашылығы саласы, ауыл шаруашылығы құрылымдары, мал мен құс басы, материалдық, жер, су ресурстары, шығыны төмен, экологиялық таза, бәсекеге қабілетті өнім.

Ключевые слова: агропромышленный комплекс, животноводческая отрасль, сельхозформирования, поголовье скота и птицы, материальные, земельные, водные ресурсы, низкозатратная, экологически чистая, конкурентоспособная продукция. 
Introduction. The general aim of agricultural development is to increase labor productivity and exports 2.5 times. Kazakhstan has a huge agraricultural potential, which makes it possible to make an actual leap forward in agriculture in the subsequent 5 years.

Agricultural economy, being one of the priority directions of the country's economic development, has big potential and huge reserves, whilst producing nearly all types of agricultural crops of the temperate climatic zone, as well as the potential to increase livestock production.

Aiming to satisfy the demand for goods on the domestic market of the Republic of Kazakhstan in connection with economic development, as well as to increase export resources, Kazakhstani company is engaged in the development, scientific justification and development of modern production technologies.

Livestock production in Kazakhstan was usually taken into account as one of the most important directions in agribusiness sector, which is also a monetary leverage for the country [1].

Based on current research, the introduction of the latest technologies suggests that increasing the competitiveness of livestock farms in the country will affect the growth in accordance with the new requirements. In this regard, it can be seen that the intention is to strengthen government assistance for the development and prosperity of livestock production and the expansion of agricultural market. The development of processing enterprises in accordance with the new requirements of the Republic of Kazakhstan requires considering the long-term programs and attracting sources of investment: tax exemption for new producers, price adjustments and their modernization in accordance with new requirements; distribution between enterprises at preferential rates, taking into account the terms of lending, etc.

Material and methods of research. The development of this industry is hindered by the lack of economic mechanisms that could stimulate all participants in the technological chain "from production to consumer". Today this whole "chain" is broken and, as a result, there are no stable links between processing enterprises and suppliers of raw materials, that is, directly with agricultural entities.

In order to improve the efficiency of the livestock industry, it is necessary:

- to create: specialized farms with medium and large-scale production, providing processing enterprises with high-quality raw materials that meet international standards;

- to build dairy complexes which are focused on consumer demand for production of deep processing products, and large feed complexes capable of producing high-quality goods in sufficient volume both for domestic consumption and for export.

In general the research performed enables to state that it is very important to increase the competitiveness of the country's livestock farms based on the introduction of latest technology into production. Besides, the willingness to strengthen public support measures will assist the livestock farms to stimulate the increase in livestock production productivity and extend agricultural product sales markets. Also, a long-term program support for the improvement of the processing enterprises in the Republic of Kazakhstan is needed, which will include tax exemption, price range, allocated for modernization and reconstruction; distribution of assets with loan rating among the businesses at preferential rates, etc. [2].

Results and their discussion. According to the Bureau of National Statistics of the Agency for Strategic Planning and Reforms of the Republic of Kazakhstan, the number of cattle at the beginning of 2020 amounted to 7 436.4 thousand heads, pigs - 813.3 thousand heads, sheep and goats - 19155.7 thousand heads, horses - 2852.3 thousand heads, camels - 216.4 thousand heads, poultry of all kinds - 45.0 million heads (table 1).

As the data in table 1 show, the number of livestock and poultry in the Republic of Kazakhstan is increasing every year.

Table 1 - The range of livestock in all classes of farms in the Republic of Kazakhstan as of January 1 (at the start of the year), thousand heads

\begin{tabular}{|c|c|c|c|c|c|c|}
\hline Year & Cattle & $\begin{array}{c}\text { Sheep and } \\
\text { goats }\end{array}$ & Pig & Horse & Camels & $\begin{array}{c}\text { Poultry, million } \\
\text { heads }\end{array}$ \\
\hline 2018 & 7150.9 & 18699.1 & 798.7 & 2646.5 & 207.6 & 44.3 \\
\hline 2019 & 7436.4 & 19155.7 & 813.3 & 2852.3 & 216.4 & 45.0 \\
\hline
\end{tabular}


The number of livestock and poultry in the Republic of Kazakhstan by category of farms is shown in table 2.

Table 2 shows that the largest number of livestock falls on household farms, and the number of poultry prevails on agricultural enterprises, mostly on large poultry farms.

Kazakhstan has vast areas of agricultural land, including those which are required to provide livestock with fodder. The main sources for providing livestock and poultry with fodder in the republic are pastures, natural and sown hayfields, arable land for growing fodder crops.

Gross livestock production is shown in table 3.

Table 2 - The wide variety of livestock and poultry in the Republic of Kazakhstan in types of farms (at the start of the year), thousand heads

\begin{tabular}{|c|c|c|c|c|c|c|}
\hline Year & Cattle & $\begin{array}{c}\text { Sheep and } \\
\text { goats }\end{array}$ & Pig & Horse & Camels & $\begin{array}{c}\text { Poultry, } \\
\text { million heads }\end{array}$ \\
\hline \multicolumn{7}{|c|}{ All categories of farms } \\
\hline 2018 & 7150.9 & 18699.1 & 798.7 & 2646.5 & 207.6 & 44.3 \\
\hline 2019 & 7436.4 & 19155.7 & 813.3 & 2852.3 & 216.4 & 45.0 \\
\hline \multicolumn{7}{|c|}{ Agricultural enterprises } \\
\hline 2018 & $\begin{array}{r}712.8 \\
\end{array}$ & 830.0 & 214.3 & 163.4 & 14.2 & 32.4 \\
\hline 2019 & 717.9 & 874.2 & 241.0 & 181.1 & 15.2 & 32.8 \\
\hline \multicolumn{7}{|c|}{ Peasant or farm households } \\
\hline 2018 & 2409.8 & 7061.8 & 93.2 & 1186.5 & 82.9 & 0.5 \\
\hline 2019 & 2624.3 & 7573.3 & 78.7 & 1321.2 & 87.4 & 0.7 \\
\hline \multicolumn{7}{|c|}{ Households of the population } \\
\hline 2018 & 4028.4 & 10807.3 & 491.2 & 1296.7 & 110.5 & 11.4 \\
\hline 2019 & 4094.3 & 10708.2 & 493.6 & 1349.9 & 113.8 & 11.6 \\
\hline
\end{tabular}

Table 3 - Production of ready-made feed for livestock in the context of regions, thousand tons

\begin{tabular}{|l|r|r|r|}
\hline & \multicolumn{1}{|c|}{2018} & \multicolumn{1}{|c|}{2019} & \multicolumn{1}{|c|}{2020} \\
\hline The Republic of Kazakhstan & 2050455.8 & 2319496.7 & 2637460.7 \\
\hline Akmola & 136878.5 & 167946.2 & 202790.8 \\
\hline Aktobe & 148838.2 & 174866.2 & 202120.1 \\
\hline Almaty & 357200.1 & 380094.0 & 430331.6 \\
\hline Atyrau & 39728.5 & 45013.9 & 48764.2 \\
\hline West Kazakhstan & 91365.8 & 107782.4 & 127066.5 \\
\hline Zhambyl & 120773.5 & 141451.9 & 161919.3 \\
\hline Karaganda & 155131.9 & 202347.2 & 215670.5 \\
\hline Kostanay & 118188.5 & 132667.3 & 160750.3 \\
\hline Kyzylordinskaya & 39561.0 & 45705.8 & 52888.5 \\
\hline Mangystau & 12552.5 & 15528.2 & 15417.8 \\
\hline South Kazakhstan & & - & - \\
\hline Pavlodar & 116175.9 & 128526.9 & 147999.6 \\
\hline North Kazakhstan & 147714.5 & 159332.3 & 178087.7 \\
\hline Turkestan & 255326.4 & 270878.7 & 304785.1 \\
\hline East Kazakhstan & 292696.4 & 326421.5 & 365954.5 \\
\hline Nur-Sultan & 189.3 & 150.5 & 151.7 \\
\hline Almaty city & 1571.6 & 1626.9 & 826.3 \\
\hline Shymkent & 16563.5 & 19156.7 & 21936.2 \\
\hline
\end{tabular}

According to table 3 , in the context of regions, the growth rates of gross agricultural output are higher than the republican ones in 10 regions: Almaty, Akmola, Aktobe, Pavlodar, Turkestan, North Kazakhstan, Zhambyl, East Kazakhstan Karaganda, Kostanay.

In livestock production, the increase in the population number of livestock and poultry of all types is observed. Thus, the population of cattle increased by $4 \%$, sheep and goats by $2.4 \%$, horses-by $7.8 \%$, poultry-by $1.6 \%$ [3].

Also, there was an increase in production of meat in live weight by $5.5 \%$ ( 1975 thousand tons), milk - by $3.1 \%$ (5 864.9 thousand tons).

Food production for the specified period increased by $3.9 \%$. 
Currently, $45 \%$ of the total gross agricultural product produced in Kazakhstan is accounted for livestock production. As part of the development of the agro-industrial complex for $2017-2021$, about $30 \%$ is allocated to subsidize investment projects in the field of livestock production.

On the basis of analysis and comparison of the potential of external markets and internal production opportunities, the main longterm priority for the development of the agroindustrial complex is determined by meat livestock production.

The adopted model is based on the traditions of nomadic distant pasture animal husbandry and the competitive advantages of Kazakhstan:

- 180 million ha of pastures (of which 58 million ha are used);

- 3.8 million people of the working rural population (of which 1.3 million people are employed in agriculture);

- proximity to the main growing markets with total imports of more than 2.0 million tons per year;

- developed crop production, which has unlimited potential for the development of a fodder base, including on irrigated lands (by 2021, the area of irrigated land will be up to 2.0 million ha, by 2030 - up to 3.0 million ha) [4].

The new approach foresees the participation of a large number of small farms in a single technological conveyor of meat production. Family farms will be engaged in raising livestock and obtaining gobies for fattening, industrial feedlots - intensive feeding, meat processing plants - industrial slaughter of livestock, deep processing and marketing of finished products.

The production of livestock products in the country is characterized by:

- low competitiveness and productivity of animals (the average annual milk yield per cow is slightly more than 2.0 thousand liters per cow, while in developed countries 6.0 thousand liters and more are produced), as well as low quality products, $74 \%$ of milk is produced by households that do not have the necessary material and technical base, veterinary and zootechnical service for production of quality products;

- high production cost and selling price;

- a low level of selection and breeding work, the number of breeding animals increases annually by an average of $5-15 \%$ (in developed countries this figure is $40-50 \%$ );

- lack of linkage between all technological links of reproduction process, rural entrepreneurs located in remote villages are far from sales markets, their raw materials remain unclaimed due to high transport costs;

- low level of development of modern technologies for production of low-cost, environmentally friendly, competitive products of the industry;

- high share of imports of meat and dairy products on the domestic market, in particular, 150-170 thousand tons of poultry meat are imported annually, etc.

Another problem in AIC is processing of agricultural products. Despite the undertaken public support measures, the share of agricultural products processing in the total production volume remains low. According to the data of the Ministry of Agriculture of the Republic of Kazakhstan, the capacities of processing plants are loaded only by $20-60 \%$. Less than $30 \%$ of produced meat, milk, fruits and vegetables are processed $[5,6]$.

The underutilization of the capacities of meat and milk processing enterprises is explained by the fact that the main livestock population is concentrated in households, where the products are sold in small batches and, mainly, on the local market. Products made at households, in many respects do not meet sanitary and hygienic requirements. Households produce $56 \%$ of meat and $74 \%$ of milk. These farms are practically unable to organize the sale of the grown crop themselves due to the small volume of their production. Therefore, they are forced to sell them at a low price to intermediaries. It is estimated that the sale of products without intermediaries will increase the workload of processing enterprises 1.3 times. And the trade margin due to the reduction of intermediary links will decrease by $15-20 \%[7,8]$.

The work of processing enterprises is negatively affected by the lack of a planned, stable supply of raw materials for processing, as well as their weak material and technical base. For example, in the meat industry, no more than $12-15 \%$ of the functioning equipment is capable of providing competitive production. The average level of mechanization at meat processing plants is $30-40 \%$, while $80 \%$ of loading and unloading operations are carried out manually. It has been determined that $50 \%$ of those working in meat processing plants also perform the work manually. To produce agricultural products with high added value, it is necessary not only to increase their volumes, but also to increase the production of finished products. For this, it is necessary to increase the supply of raw materials to processing enterprises. 
Based on general research, it is necessary to introduce modern technologies into production of agricultural products according to the latest models and to increase the competitiveness of the country's livestock industry on the world market.

Kazakhstan occupies a special place in economic, social and cultural development. The well-being and the living standard of the population are almost completely determined by the livestock population number. Livestock production in Kazakhstan needs replacement of pastures, and therefore, the need for increasing public support for livestock production development is noted $[9,10]$.

There are still many unresolved issues in agriculture. The most important thing is to provide the population with high-quality, nutritious and affordable food, protect the environment from pollution and improve the use of natural resources, as well as find sources of effective investment in livestock production.

This will ensure the country's food security, increase the income of rural entrepreneurs, provide 2.5 times increase of labor productivity and 2 times increase of export of agricultural products.

\section{Conclusion}

1. For the increase of the livestock productivity it is necessary:

- to create: medium and big production farms, which offer the processing enterprises raw substances that meet global standards;

- construction of customer dairy complexes for production of deeply processed merchandise and huge feed turbines able to produce enough quantity of exceptional products for domestic consumption and for export.

2. In general, there is an aim to increase the competitiveness of the country's livestock farms through the creation of the latest advanced technologies and their introduction into production. There is also the need to extend the range of the assistance of the authorities for the cattle breeding sector aimed to enhance cattle productivity and extend the agricultural product market.

\section{References}

[1] Зубарева, Ю.В. Проблемы агробизнеса и направления их решения / Ю.В. Зубарева, Л.М. Пилипенко // Фундаментальные исследования. - 2016. - №12 (4). - С. 858-862.

[2] Молдашев, А.Б. Агропромышленный комплекс Казахстана: проблемы развития и поиск путей их решения / А.Б. Молдашев // Проблемы аграрного рынка.- 2016.-N 3.- C.7-13.
[3] Ермолаева, С.Г. Рынок труда: учеб. для вузов / С.Г. Ермолаева.- Екатеринбург: Уральский университет, 2015. - 108 с.

[4] Трудовые ресурсы [Электронный ресурс]. - 2018. - URL: https: //ru.wikipedia. org/wiki/Labor_resources (дата обращения: 15.10.2019).

[5] Radhakrishna A., Satya Raju R. Research on the Impact of Human Resource Development on Labor Relations / A. Radhakrishna, R. Satya Raju // Journal of Management Research. Business Source Complete.- 2015. N.4.- P. 156-167.

[6] Статистика и анализ трудовых ресурсов [Электронный ресурс]. - 2018.-URL: http://www.grandars.ru/student/statistika/trudovy e-resursy.html (дата обращения: 22.10.2019).

[7] Экономика сельского хозяйства: учеб. / под ред. Н.Я. Коваленко. - М: Юрайт, 2018. $406 \mathrm{c}$.

[8] Сельское, лесное и рыбное хозяйство в Республике Казахстан за 2014-2018 годы: стат.сборник. - Нур-Султан: Бюро национальной статистики Агенства по стратегическому поанированию и реформам Республики Казахстан, 2019.- 207 с.

[9] Занятость в Казахстане на 2014-2018 годы: стат. сборник.- Нур-Султан: Бюро национальной статистики Агенства по стратегическому поанированию и реформам Республики Казахстан, 2019. - 248 с.

[10] Абакарова, Р.Ш. Регулирование сельского хозяйства. Положительные аспекты зарубежного опыта/ Р.Ш. Абакарова//Вестник Иркутского государственного технического университета.-2015.- №1(96).-С.129-132.

\section{References}

[1] Zubareva Yu.V., Pilipenko L.M. (2016) Problems of Agribusiness and Directions for Their Solution. Fundamental'nye issledovanijaFundamental Research, 12 (4), 858-862 [in Russian].

[2] Moldashev A.B. (2016) Agro-industrial complex of Kazakhstan: development problems and search for their solution. Problemy agrorynka - Problems of AgriMarket, 3, 7-13 [in Russian].

[3] Ermolaeva S.G. (2015) Labor market: textbook. allowance. Yekaterinburg: Ural University. Available at: http: //elar.urfu.ru/bitstream/ 10995/30847/1/978-5-7996-1393-8.pdf (date of access: 9.10.2019) [in Russian].

[4] Labor resources [Electronic resource]. 2018. -URL: https://ru.wikipedia.org/wiki/Labor resources (date accessed: 15.10.2019) [in Russian].

[5] Radhakrishna A., Satya Raju R. (2015). Research on the Impact of Human Resource Development on Labor Relations / A. Radha- 
krishna, R.Satya Raju. Journal of Management

Research. Business Source Complete, 4, 156-167.

[6] Statistika i analiz trudovyh resursov [Statistics and analysis of labor resources] (2018). Available at: http: //www.grandars.ru/ student/statistika/trudovye-resursy.html (date of access: 22.10.2019) [in Russian].

[7] Jekonomika sel'skogo hozjajstva: ucheb. / pod red. N.Ja. Kovalenko [Agricultural Economics: Textbook / ed. N.Ya. Kovalenko] (2018). Moscow: Jurajt, 406 [in Russian].

[8] Sel'skoe, lesnoe i rybnoe hozjajstvo v Respublike Kazahstan za 2014-2018 gody: stat. sbornik [Statistical collection "Agriculture, forestry and fisheries in the Republic of Kazakhstan for 2014-2018"] (2019). Nur-Sultan: Bjuro nacio- nal'noj statistiki Agenstva po strategicheskomu poanirovaniju i reformam Respubliki Kazahstan, 207 [in Russian].

[9] Zanjatost' v Kazahstane na 2014-2018 gody: stat. sbornik [Statistical collection "Employment in Kazakhstan for 2014-2018"] (2019) Nur-Sultan: Bjuro nacional'noj statistiki Agenstva po strategicheskomu poanirovaniju i reformam Respubliki Kazahstan, 248 [in Russian].

[10] Abakarova, R.Sh. (2015) Regulirovanie sel'skogo hozjajstva. Polozhitel'nye aspekty zarubezhnogo opyta [Agricultural regulation. Positive aspects of foreign experience]. Vestnik Irkutskogo gosudarstvennogo tehnicheskogo universiteta - Irkutsk State Technical University Bulletin, 1 (96), 129-132 [in Russian].

Information about authors:

Nurgalieva Ainash Amangeldinovna - The main author; Candidate of Economic Sciences, Associate Professor; Associate Professor of the Department of Economics; Toraigyrov University; 140008 Lomov str., 64, Pavlodar, Kazakhstan; e-mail: nurgalieva_ainash@mail.ru; https://ORCID.org/0000-00023818-7013

Khassenova Klara Ergeshbaevna; Candidate of Economic Science, Associate Professor; Head of the Educational Program "Finance"; Shakarim University; 071412 Glinka str., 20a, Semey, Kazakhstan; e-mail: klarita_khassenova@mail.ru; https://orcid.org/0000-0002-0063-8536

Kenzhetaeva Gulbaram; Master of Economics; Senior Lecturer of the Department of Economics; Toraigyrov University; 140008 Lomov str., 64, Pavlodar, Kazakhstan; e-mai:I qulmira74@mail.ru; https://orcid.org/0000-0002-6306-527X

\section{Авторлар туралы ақпарат:}

Нұрғалиева Айнаш Амангелдинқызы - негізгі автор; экономика ғылымдарының кандидаты, қаумдастырылған профессоры; «Экономика» кафедрасының қаумдастырылған профессоры; Торайғыров университеті; 140008 Ломов көш., 64, Павлодар қ., Қазақстан; e-mail: nurgalieva_ainash@mail.ru; https://ORCID.org/0000-0002-3818-7013

Хасенова Клара Ергешбайқызы; экономика ғылымдарының кандидаты, қаумдастырылған профессор; «Қаржы» білім беру бағдарламасының жетекшісі; Shakarim University; 071412 Глинка көш., 20 a, Семей қ., Қазақстан; e-mail:klarita_khassenova@mail.ru; https://orcid.org/0000-0002-0063-8536

Кенжетаева Гульбарам Кашаубайқызы; экономика магистрі; «Экономика» кафедрасының аға оқытушысы; Торайғыров университеті; 140008 Ломов көш., 64, Павлодар қ., Қазақстан; e-mail: qulmira74@mail.ru; https://orcid.org/0000-0002-6306-527X

\section{Информация об авторах:}

Нургалиева Айнаш Амангельдиновна - основной автор; кандидат экономических наук, ассоиированный профессор; ассоциированный профессор кафедры «Экономика»; Торайгыров университет; 140008 ул. Ломова, 64, г.Павлодар, Казахстан; e-mail: nurgalieva_ainash@mail.ru; https://ORCID.org/0000-0002-3818-7013

Хасенова Клара Эргешбаевна; кандидат экономических наук, ассоциированный профессор; руководитель образовательной программы «Финансы»; Университет им. Шакарима; 071412 ул. Глинка, 20 а, г. Семей, Казахстан; e-mai: klarita_khassenova@mail.ru; https://orcid.org/ 0000-00020063-8536

Кенжетаева Гульбарам Кашаубаевна; магистр экономики; старший преподаватель кафедры «Экономика»; Торайгыров университет; 140008 ул. Ломова, 64, г.Павлодар, Казахста; е-mai: qulmira74@mail.ru; https://orcid.org/ 0000-0002-6306-527X 